\title{
РОЛЬ МЕДСЕСТРИ В ПРОФІЛАКТИЦІ ТУБЕРКУЛЬОЗУ СЕРЕД ПІДЛІТКІВ СТАРШИХ КЛАСІВ
}

\author{
А. В. Перепелиця
}

Вищий навчальний заклад «Київський міський медичний коледж»

У статті розглянуто актуальну проблему захворюваності на туберкульоз серед підлітків України. Проаналізовано сучасну ситуацію з профілактичних методів туберкульозу в закладах освіти. Акцентовано увагу на необхідності залучення медичної сестри до підвищення рівня знань підлітків старших класів із метою вдосконалення профілактики туберкульозу на етапі попередження та виявлення захворювання.

\section{THE ROLE OF A NURSE IN PREVENTION OF TUBERCULOSIS AMONG THE TEENAGERS OF THE SENIOR CLASSES}

\section{A. V. Perepelytsia}

\section{Kyiv City Medical College}

The article deals with the actual problem of teenagers' tuberculosis morbidity of Ukraine. The modern situation with the prevention methods of tuberculosis in educational institutions is analyzed. The necessity of implementation of the nurse to the process of increasing of the knowledge level of teenagers of the senior classes is emphasized with the aim of improvement of tuberculosis prophylaxis at the stage of prevention and disease discovering.

Вступ. Серед соціальних та медичних проблем суспільства захворювання на туберкульоз посідає особливе місце. Туберкульоз (ТБ), за визначенням провідних вчених, продовжує залишатися глобальною проблемою, особливо серед дитячого населення. Сучасна ситуація не сприяє появі оптимістичних прогнозів - із року в рік туберкульоз набуває все більш небезпечних форм і ставить під загрозу життя та здоров'я дітей.

На жаль, молодь нашої країни у абсолютній своїй кількості не єздоровою. І вже у 15-16 років має хронічні захворювання, а до досягнення 18 років практично усі вже $\epsilon$ інфікованими туберкульозом. Науковцями відмічено, що підлітки останнім часом почали хворіти на форми туберкульозу, властиві дорослим, помітно підвищився відсоток хворих із ускладненим перебігом хвороби, при цьому найчастіше спостерігають прогрес процесу з розвитком менінгіту, міліарного туберкульозу та казеозної пневмонії. Це стосується насамперед дітей-підлітків, в яких імунна система $\epsilon$ недосконалою і не має ефективного захисту від туберкульозу. Не потрібно забувати і про особливості сучасного підлітка, який через прагнення самоутвердитися, зрівнятися або хоча 6 здаватися таким,

(c) А. В. Перепелиця, 2016 як дорослі, виокремитися серед однолітків, здобути очікувані позиції у групі, самостійно діяти, досить часто починає курити, вживати алкоголь, що збільшує ризик розвитку туберкульозу.

Вищевказане свідчить про необхідність перегляду профілактичних заходів на етапі роботи зі здоровим населенням, зокрема підлітками старших класів у навчальних закладах. А підвищення опірності організму підлітка повинно бути справою першорядної важливості як щодо всіх захворювань загалом, так особливо до туберкульозу. Особлива роль, на нашу думку, у вирішенні цієї проблеми повинна належати середньому медичному персоналу первинної ланки, а саме медичній сестрі навчального закладу.

Отже, об'єктом обговорення в даній статті $є$ профілактичні методи туберкульозу в закладах освіти. Предметом виступає роль медичної сестри в профілактиці туберкульозу серед підлітків старших класів. Маємо за мету дослідити рівень знань старшокласників про туберкульоз та сформувати рекомендації для медичної сестри при роботі з вказаною категорією учнів.

Основна частина. Підлітковий туберкульоз займає в клініці значне місце. У той час як у дітей виявляють переважно первинні форми туберкульозу (90-93 \%), а в дорослих - вторинні (до 90 \%), то у підлітків одна- 
ковою мірою виявляють і первинні, і вторинні форми туберкульозу.

Серед первинних форм туберкульозу частіше спостерігають первинний туберкульозний комплекс, бронхоаденіт, хронічний первинний туберкульоз, серед вторинних - інфільтративний туберкульоз легень.

Перебіг первинного туберкульозу в підлітків подібний до перебігу первинних форм у дітей, але результат більш сприятливий. Разом із тим не виключена можливість ускладненого перебігу первинного туберкульозу, при якому спостерігають формування первинних каверн, обсіменіння з утворенням дочірніх каверн, залучення в процес периферійних і мезентеріальних лімфатичних вузлів. У цих випадках захворювання набуває хронічного характеру, а відкладання вапна у вогнищах відбувається повільніше і виражене меншою мірою, ніж у дітей.

Хронічний первинний туберкульоз у підлітків перебігає зазвичай у вигляді казеозного бронхоаденіту й описують в літературі як юнацький туберкульоз. Характерною ознакою хронічного первинного туберкульозу є залучення в процес кісток, суглобів, очей, нових груп лімфатичних вузлів із їх тотальним або частковим казеозом, туберкульозним ураженням шкіри у вигляді скрофулодерми і формуванням нориць. У підлітковому періоді свіжі або хронічні форми первинного туберкульозу іноді складно відокремити від процесів вторинного походження, тому що клініка туберкульозу в підлітків відрізняється значним поліморфізмом.

Вторинний туберкульоз у підлітків відрізняють схильністю до значних інфільтративно-пневмонічних реакцій з утворенням поодиноких і множинних каверн і наступним прогресуванням захворювання [1, 2].

Крім описаних відмінностей необхідно відмітити, що підлітки останнім часом почали хворіти на форми туберкульозу властиві дорослим. Це може бути зумовлено акселерацією, інтенсивним ростом, різкими змінами гормонального фону, супутніми патологіями. У зв'язку з гормональною перебудовою в підлітків, так само, як у дітей, зберігаються нестійкість імунітету, підвищена чутливість, що зумовлює розвиток форм туберкульозу, що гостро перебігають.

Потужними негативними чинниками $є$ також раннє статеве життя, порушення режиму дня та харчування, вживання алкоголю (одноразове або систематичне), тютюнокуріння (яке призводить до токсичного ураження верхніх дихальних шляхів). Усе це є факторами ризику виникнення туберкульозу.
Необхідно зазначити, що перераховані прояви негативної поведінки пов'язані з особливостями вікового періоду (бажання звільнитися від опіки й контролю з боку старших, батьківського або групового наслідування) та низьким рівнем знань про можливі наслідки, в тому числі, і виникнення туберкульозу.

На жаль, на сьогодні вкрай мало навчальних закладів, які проводять заходи з пропаганди здорового способу життя та профілактики туберкульозу. У більшості випадків з боку педагогічного складу відбувається лише загострення ситуації через критику та соціальне приниження підлітка, що призводить до конфліктних ситуацій та асоціальної поведінки.

Головною причиною такої поведінки, на нашу думку, виступає низький рівень знань про захворювання та профілактичні методи з його попередження. 3 метою підтвердження нашої гіпотези було проведено дослідження серед 175 учнів 8-10 класів (8 класів 61 учень, 9 класів - 60 учнів, 10 класів - 54 учні) двох шкіл міста Києва, яке складалося з двох етапів: анкетування та опитування.

На першому етапі респондентам було запропоновано анкету з 14 питань та варіантами відповідей.

Після інтерпретації отриманих даних були сформовані кількісні результати, які наведено в таблиці 1.

У результаті отриманих даних встановлено, що більшість підлітків має низький рівень знань з туберкульозу, його шляхів зараження, значення БЦЖ та тесту Манту. Результати свідчать про відсутність знань про здоровий спосіб життя, його значення в підлітковому віці та свідомого поєднання куріння з ризиком туберкульозу. Також було виявлено, що більшість учнів вважає, що їм туберкульоз не загрожує.

Під час аналізу порівняльних результатів, отриманих по класах, встановлено відмінність у деяких питаннях, а саме: 6,10 . Це свідчить про вищий рівень у старших класах знань про вплив куріння та вживання алкоголю на ослаблення організму в підлітковому віці (серед учнів 9 класу на 6,76 \% порівняно з респондентами 8 класу, серед представників 10 класу на 5,62 \% порівняно з 9 класом і 12,38 \% з 8 класом), але нижчі показники зі взаємозв'язку куріння з можливим розвитком туберкульозу (на 8,89 \% порівняно 3 результатами учнів 9 класу). Однак вказані результати статистично незначущі і не мають рушійної сили у загальних показниках.

Другим етапом нашого дослідження було проведення опитування, яке складалося з 3 питань: 
таблиця 1. Результати анкетування серед учнів 8, 9 та 10 класів

\begin{tabular}{|c|c|c|c|c|c|c|c|c|c|}
\hline \multirow{2}{*}{$\begin{array}{l}\text { № } \\
\text { 3/ח }\end{array}$} & \multirow{2}{*}{ Питання } & \multicolumn{2}{|c|}{8 клас } & \multicolumn{2}{|c|}{9 клас } & \multicolumn{2}{|c|}{10 клас } & \multicolumn{2}{|c|}{$\begin{array}{c}\text { Загальний } \\
\text { показник }\end{array}$} \\
\hline & & кількість & $\%$ & кількість & $\%$ & кількість & $\%$ & кількість & $\%$ \\
\hline 1 & \multicolumn{9}{|c|}{ Туберкульоз - це інфекційне захворювання? } \\
\hline a) & так & - & - & 2 & 3,33 & 1 & 1,85 & 3 & 1,71 \\
\hline 6) & $\mathrm{Hi}$ & 6 & 9,84 & 8 & 13,33 & 10 & 18,52 & 24 & 13,72 \\
\hline B) & не знаю & 55 & 90,16 & 50 & 83,40 & 43 & 79,63 & 148 & 84,57 \\
\hline 2 & \multicolumn{9}{|c|}{ Існують інші види туберкульозу, окрім легеневого? } \\
\hline a) & так & - & - & 2 & 3,33 & 1 & 1,85 & 3 & 1,71 \\
\hline 6) & $\mathrm{Hi}$ & 6 & 9,84 & 8 & 13,33 & 10 & 18,52 & 24 & 13,72 \\
\hline B) & не знаю & 55 & 91,80 & 50 & 83,40 & 43 & 79,63 & 148 & 84,57 \\
\hline 3 & \multicolumn{9}{|l|}{ На туберкульоз хворіють: } \\
\hline a) & $\begin{array}{l}\text { люди усіх вікових категорій та } \\
\text { свійські тварини }\end{array}$ & - & - & - & - & - & - & - & - \\
\hline 6) & діти та дорослі & 5 & 8,20 & 10 & 16,60 & 11 & 20,37 & 26 & 14,86 \\
\hline B) & дорослі та люди похилого віку & 56 & 91,80 & 50 & 83,40 & 43 & 79,63 & 149 & 85,14 \\
\hline 4 & \multicolumn{9}{|c|}{ Туберкульозом можна заразитись у таких місцях: } \\
\hline a) & на вулиці & 3 & 4,92 & 11 & 18,33 & 10 & 18,52 & 24 & 13,72 \\
\hline 6) & у лікарні, поліклініці & 58 & 95,08 & 47 & 78,34 & 43 & 79,63 & 148 & 84,57 \\
\hline B) & в школі & - & - & 2 & 3,33 & 1 & 1,85 & 3 & 1,71 \\
\hline 5 & \multicolumn{9}{|c|}{ Туберкульозом можна заразитись при: } \\
\hline a) & $\begin{array}{l}\text { споживанні сирого молока, } \\
\text { яєць, непровареного м'яса }\end{array}$ & - & - & - & - & - & - & - & - \\
\hline 6) & $\begin{array}{l}\text { спілкуванні з людиною, яка } \\
\text { кашляє та чхає }\end{array}$ & 58 & 95,08 & 55 & 91,67 & 52 & 96,40 & 165 & 94,29 \\
\hline B) & курінні чужих недопалків & 3 & 4,92 & 5 & 8,33 & 2 & 3,60 & 10 & 5,71 \\
\hline 6 & \multicolumn{9}{|c|}{ Чи може куріння та вживання алкоголю ослабити організм у підлітковому віці? } \\
\hline a) & так & 6 & 9,84 & 10 & 16,60 & 12 & 22,22 & 28 & 16,00 \\
\hline 6) & $\mathrm{Hi}$ & 20 & 32,79 & 25 & 41,70 & 23 & 42,59 & 68 & 38,86 \\
\hline B) & не знаю & 35 & 57,37 & 25 & 41,70 & 19 & 35,19 & 79 & 45,14 \\
\hline 7 & \multicolumn{9}{|c|}{ Вірогідність захворювання на туберкульоз знижується при: } \\
\hline a) & $\begin{array}{l}\text { правильному харчуванні, } \\
\text { здоровому способі життя }\end{array}$ & 2 & 3,28 & 8 & 13,33 & 6 & 11,11 & 16 & 9,15 \\
\hline 6) & \begin{tabular}{|l|} 
відмові від куріння та \\
вживання алкоголю \\
\end{tabular} & 5 & 8,20 & 5 & 8,33 & 5 & 9,26 & 15 & 8,57 \\
\hline B) & $\begin{array}{l}\text { обмеженні відвідувань } \\
\text { лікарень }\end{array}$ & 54 & 88,52 & 47 & 78,34 & 43 & 79,63 & 144 & 82,28 \\
\hline 8 & \multicolumn{9}{|c|}{ Вірогідність захворювання на туберкульоз знижується при: } \\
\hline a) & $\begin{array}{l}\text { дотриманні правил особистої } \\
\text { гігієни }\end{array}$ & 1 & 1,64 & - & - & - & - & 1 & 0,57 \\
\hline 6) & $\begin{array}{l}\text { проведенні щеплень та } \\
\text { заходів із зміцнення здоров'я }\end{array}$ & - & - & 2 & 3,33 & 1 & 1,85 & 3 & 1,71 \\
\hline B) & $\begin{array}{l}\text { обмеженні спілкування з } \\
\text { соціально незахищеними } \\
\text { особами («бомжами», } \\
\text { алкоголіками та ін.) }\end{array}$ & 60 & 98,36 & 58 & 96,67 & 53 & 98,15 & 171 & 97,72 \\
\hline 9 & \multicolumn{9}{|c|}{ Чи може школяр захворіти на туберкульоз? } \\
\hline a) & так & - & - & 2 & 3,33 & 1 & 1,85 & 3 & 1,71 \\
\hline 6) & $\mathrm{Hi}$ & 30 & 49,18 & 27 & 45,00 & 20 & 37,04 & 77 & 44,00 \\
\hline B) & не знаю & 31 & 50,82 & 31 & 51,67 & 33 & 61,11 & 95 & 54,29 \\
\hline
\end{tabular}


Продовження табл. 1.

\begin{tabular}{|c|c|c|c|c|c|c|c|c|c|}
\hline 1 & 2 & 3 & 4 & 5 & 6 & 7 & 8 & 9 & 10 \\
\hline 10 & \multicolumn{9}{|c|}{ Чи може куріння викликати туберкульоз? } \\
\hline a) & так & 5 & 8,20 & 5 & 8,33 & 5 & 9,26 & 15 & 8,57 \\
\hline б) & $\mathrm{Hi}$ & 13 & 21,30 & 8 & 13,33 & 12 & 22,22 & 33 & 18,86 \\
\hline B) & я не впевнений (а) & 43 & 70,50 & 47 & 78,34 & 37 & 68,52 & 127 & 72,57 \\
\hline 11 & \multicolumn{9}{|l|}{ БЦЖ проводять для... } \\
\hline a) & лікування туберкульозу & 10 & 16,39 & 12 & 20,00 & 7 & 12,96 & 29 & 16,57 \\
\hline б) & $\begin{array}{l}\text { вироблення імунітету проти } \\
\text { туберкульозу }\end{array}$ & - & - & - & - & - & - & - & - \\
\hline B) & не знаю & 51 & 83,60 & 48 & 80,00 & 47 & 87,04 & 146 & 83,43 \\
\hline 12 & \multicolumn{9}{|l|}{ Пробу Манту проводять для... } \\
\hline a) & $\begin{array}{l}\text { профілактичного обстеження } \\
\text { на туберкульоз }\end{array}$ & 10 & 16,39 & 12 & 20,00 & 7 & 12,96 & 29 & 16,57 \\
\hline б) & лікування туберкульозу & - & - & - & - & - & - & - & - \\
\hline B) & не знаю & 51 & 83,60 & 48 & 80,00 & 47 & 87,04 & 146 & 83,43 \\
\hline 13 & \multicolumn{9}{|c|}{ Чи потрібно школяру зміцнювати здоров'я та вести здоровий спосіб життя? } \\
\hline a) & так & 10 & 16,39 & 12 & 20,00 & 9 & 16,67 & 31 & 17,71 \\
\hline б) & Hi & 8 & 13,11 & 10 & 16,67 & 8 & 14,81 & 26 & 14,86 \\
\hline B) & не знаю & 43 & 70,50 & 38 & 63,33 & 37 & 68,52 & 118 & 67,43 \\
\hline 14 & \multicolumn{9}{|c|}{ На твою думку, для тебе $\epsilon$ небезпека захворіти на туберкульоз? } \\
\hline a) & так & - & - & - & - & - & - & - & - \\
\hline б) & Hi & 50 & 81,97 & 48 & 80,00 & 45 & 83,33 & 143 & 81,71 \\
\hline B) & мало вірогідно & 11 & 18,03 & 12 & 20,00 & 9 & 16,67 & 32 & 18,29 \\
\hline
\end{tabular}

1. Чи хотіли б Ви дізнаватися про вплив куріння, алкоголю на організм та значення здорового способу життя в підлітковому віці?

2. Чи хотіли 6 Ви дізнатися про туберкульоз, його профілактику, БЦЖ та пробу Манту?

3. Чи відвідували 6 Ви лекційні та тренінгові заняття з теми «Туберкульоз», «Здоровий спосіб життя» та ін.?

Внаслідок опитування було отримано інформацію, яка свідчить, що більшість підлітків висловлювала бажання підвищити свій рівень знань стосовно здорового способу життя та небезпечних захворювань, зокрема туберкульозу. А саме:

- 125 осіб на 3 питання дали відповідь «так»;

- 15 осіб відповіли «так», але не впевнені, що це буде цікаво;

- 15 осіб обрали відповідь «ні», тому що вважають, що знають достатньо;

- 20 осіб дали відповідь «ні», бо не вважають це за потрібне.

Для наочної демонстрації отримані результати наведено на рисунку 1.

Внаслідок проведеного дослідження вважаємо за потрібне в роботу медичної сестра закладів освіти при профілактиці туберкульозу включати такі заходи:

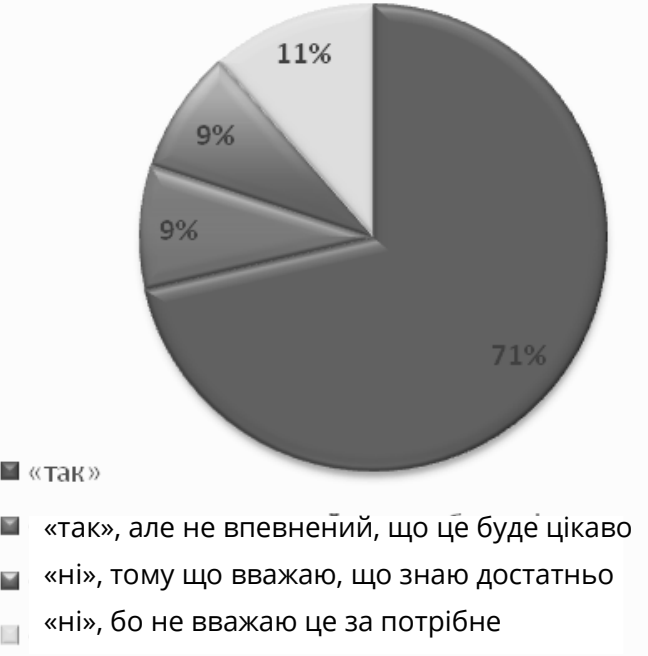

Puc. 1. Результати опитування підлітків старших класів (\%).

- проведення анкетування на визначення рівня знань з туберкульозу серед підлітків старших класів;

- проведення інформаційно-просвітницьких заходів серед учнів щодо профілактики туберкульозу;

- створити у класі «Куток здоров'я», де зосередити матеріали з профілактики туберкульозу (санітарні бюлетені, стінгазети, конкурс малюнків тощо); 
- проведення лекцій з залученням викладачів, психолога, фтизіатрів;

- проведення тренінгових занять;

- організація шкільних заходів до Всесвітнього дня боротьби з туберкульозом (24 березня).

Висновки. 1. Проблема профілактики туберкульозу серед підлітків старших класів залишається найакту-

\section{ЛІТЕРАТУРА}

1. Русакова Л. И. Остро прогрессирующие формы легочного туберкулёза у подростков / Л. И. Русакова // Проблемы туберкулёза. - 2001. - № 1. - С. 31-34. альнішою, і основну роль у їі вирішенні повинен відігравати середній медичний персонал закладів освіти.

2. Робота медичної сестри зі здоровим населенням має нести профілактичну спрямованість через підвищення рівня знань зі здорового способу життя, запобігання розвитку небезпечних захворювань, зокрема туберкульозу.

2. Фирсова В. А. Туберкулёз у подростков: диагностика, клиника, лечение / В. А. Фирсова // Проблемы туберкулёза. - 2003. - № 3. - С. 23-26. 